Elsevier required licence: (C) <2019>. This manuscript version is made available under the CC-BY-NCND 4.0 license http://creativecommons.org/licenses/by-nc-nd/4.0/

The definitive publisher version is available online at [http://doi.org/10.1016/j.mhp.2019.02.002] 


\title{
Attachment problems in childhood and the development of anxiety in adolescents: \\ A systematic review of longitudinal and prospective studies
}

\author{
Lawrence T Lam ${ }^{1,2}$ \\ Akshay Rai ${ }^{2}$ \\ Mary K Lam ${ }^{2}$ \\ ${ }^{1}$ Tung Wah College, Hong Kong SAR, China \\ ${ }^{2}$ Faculty of Health, University of Technology Sydney, Australia
}

Correspondence to:

Lawrence T Lam

Tung Wah College

31 Wylie Road, Homantin, Kowloon

Hong Kong SAR

CHINA

Faculty of Health, University of Technology Sydney,

235 Jones Street, Ultimo, Syndey

AUSTRALIA

Mobile: $\quad+85259783416$

E-mail: $\quad$ Lawrence.Lam@uts.edu.au; LawrenceLam@twc.edu.hk 


\begin{abstract}
The association between early relationships and the experience of infant and mother, and the subsequent development of the child through their life span has long been studied. Attachment, as a most prominent construct in early child development, has been the focal point of investigation since the inception of the theoretical concept by Bowlby. In recent years, research has expanded to examine the effect of attachment on the mental health and socio-emotional development of young children and their on-going adjustment into adolescence. However, most studies in the field concentrated on the relationship of childhood attachment and internalising symptoms as a generic assessment of mental health problems. To provide more precise information on the effect of attachment insecurity on individual mental health problems, a systematic review (the first in a series) of available longitudinal and prospective studies was conducted. 11 studies were identified after an extensive search of the literature in accordance to the PRISMA guidelines. Of these, 4 satisfied all selection criteria and provided sufficient data on the effect of attachment insecurity during infancy or early childhood and anxiety in adolescence. Information was extracted and analysed systematically from each study and tabulated. The overall results obtained from these studies indicated a significant and possible causal relationship between attachment insecurity during infancy or early childhood and the development of anxiety in adolescence. These results were discussed in light of theoretical and practical preventive implications.
\end{abstract}

Keywords: Attachment; Anxiety; Mother and Child; Longitudinal studies; Health Effect; Systematic Review 


\section{INTRODUCTION}

Attachment theory was first proposed by John Bowlby as a conceptual framework to understand human development, particularly during the very early period of infancy and early childhood [1]. Starting from the initial, mainly survival, function of attachment of infant to parent (particularly the mother), the theory highlights the importance of early attachment experiences on a broad range of childhood and adult development [1]. The framework has been established as a prominent developmental theory, with important contributions by Ainsworth and colleagues' Strange Situation Procedures (SSP, [2]).

While applying the SSP to young children and their mothers, Ainsworth et al observed that different young children responded differently to their mother when the mother-child dyad was reunited after a short, yet stressful separation [2]. Based on these observations, Ainsworth et al postulated four types of attachment behaviours [2]. In most cases, the child was able to attach to the mother securely using the mother as a secure base for exploration when the mother was present and resolve his/her distress effectively again using the mother as a source of comfort (secure attachment). However, some ignored their mothers upon reunion yet they were still anxious (avoidance). Others demonstrated ambivalence behaviours where, on the one hand, they exhibited a desire to seek comfort from the mother but, on the other, were not effectively soothed by contact with the mother (resistance). In some cases, the child exhibited behaviours that totally deviated from the normal pattern reflecting a breakdown in any attachment (disorganisation) [3]. Of interest to most researchers, and as reflected from the literature, were comparisons between the secure and other attachment behaviours including insecure attachment and disorganisation. Hence, the current study also adopts this classification.

The association between early relationships and the experience of infant and mother, and the subsequent development of the child through their life span has long been postulated [4]. With the rise in popularity of attachment theory, much attention has been paid to the relationship between parent-child attachment and psychosocial development among young children. Most studies focused on mother-child dyads [5-7]. In recent years, research has expanded to examine the effect of attachment on the mental health and socio-emotional development of young children and their on-going adjustment into adolescence [8-12]. In the growing volume of literature on the relationship between attachment and mental health issues, externalising problematic behaviours and internalising symptoms have been the main foci $[13,14]$. In 2010, Groh and colleagues [14] conducted a systematic review and metaanalytic study to explore the relationship between infant and childhood attachment and internalising symptoms, including anxiety, depression, and somatic complaints. After reviewing 42 independent studies with a total sample size of 4614 , the international team found that, irrespective of the age of assessment of the internalising symptoms, there was a small yet significant association between insecure attachment of the infant to the mother and internalising symptoms with a small estimated effect size of about $0.15(\mathrm{~d}=0.15,95 \%$ C.I. $=0.06-0.25$ ). Similar results were also found for those young children who had exhibited avoidant attachment behaviour and internalising symptoms with an estimated effect size of $0.17(\mathrm{~d}=0.17,95 \%$ C.I. $=0.03-0.31)$.

As the first meta-analytic study in this area, Groh and colleagues adopted a thorough approach, with the inclusion of longitudinal studies and the provision of quantitative estimate on the effect size [14]. However, there was a major limitation. The study focused on internalising symptoms as a generic outcome measure of a spectrum of many different problematic mental health issues in early childhood. These mental health issues might also 
have a significant impact on on-going development and adjustment into adolescence. The effect of poor attachment at infancy and during early childhood on the development of different mental health issues, such as anxiety and depression, might vary and also developed different causal pathways, depending on the nature and the formulating characteristics of these disorders. Considering these different mental health issues as a single group is a very broad conceptual classification for a precise calculation of a quantitative measure in effect size. The small effect size estimated might be due to a dilution effect of the inclusion of the stronger effect of attachment on one or two mental health problems, with some other weaker effects. To bridge this gap, the aim of the current study is to examine the effect of poor attachment, including insecurely attached, avoidance, resistance, and disorganisation, on the subsequent development of various prominent mental health problems in adolescents. As the first of a series of examinations, this study focuses on the effect of poor attachment in infancy, and early and mid-childhood, on the development of anxiety in adolescents.

\section{METHODS}

PRISMA guidelines for systematic reviews were followed during the literature search and the subsequent review process to ensure a structured and systematic approach [15]. Five major medical, developmental, and psychological literature databases were searched including (1) PubMed, (2) SCOPUS, (3) CINAHL, (4) Web of Science, and (5) ERIC.

For the current topic of attachment problems and anxiety, the syntax used for the search was: ("attachment" OR "mother infant attachment" OR "maternal attachment" OR "infant attachment" OR "Secure attachment" OR "insecure attachment" OR "ambivalent attachment" OR "attachment styles" OR "attachment behaviour" OR "parent infant attachment" OR "mother infant relations") AND ("anxiety" OR " separation anxiety" OR "general anxiety" OR "social anxiety" OR "generalised anxiety disorder" OR "anxiety symptoms"), with syntax entry being slightly modified as per database requirements. Restrictions were imposed to ensure the studies returned were peer-reviewed journal articles in English, published in the last two decades between 1990 and November 2017.

The software 'EndNote' was used to organise, store, and collect the titles and abstracts retrieved from the initial literature search. Several steps were undertaken to ensure that studies selected for final data extraction were of high suitability in accordance of this review's aims:

Titles were assessed for relevance by analysing keywords within the title

1. Following title assessment, the third author conducted initial analysis on the abstracts to ensure sample age was between $0-18$ years, and that the study type was longitudinal. Abstracts were also analysed independently by the first and third authors for accurate section.

2. Following abstract assessment, full texts were examined in order to assess suitability for final data extraction into a table of contents. The second and third authors reviewed the full texts independently, leading to a general consensus. Any disputes were mediated by the first author.

3. Reference lists for the papers chosen for data extraction were also examined in order to procure relevant studies that might have been missed during initial literature search.

For the selection of studies, the following criteria were applied in order to identify publications suitable for inclusion in this systematic review: 
1. Publications with a longitudinal study design, published between 1990 and November 2017;

2. Studies that provided clear descriptive statistics, allowing the authors to accurately assess whether attachment assessment was conducted during infancy or early-tomid-childhood, with a follow-up assessment for anxiety symptoms conducted during early to late adolescence;

3. Studies did not include maternal figures with pre-existing mental health disorders such as depression or anxiety;

4. Studies included the tools, procedure, and analysis results for both the attachment assessment to maternal figure, and the follow-up mental health assessment;

5. Studies published in the English language for full comprehension of the content;

6. Outcomes that were not related to anxiety were excluded from this review.

After final assessment of paper suitability, data was extracted into a table of contents. The information extracted included study location, description of study design, and information on the demographic characteristics of the sample. Also reported were the tools or instruments used to assess attachment of the child and anxiety, as well as the results relating to the relationship between attachment styles in early to mid-childhood, and anxiety symptoms in early to late adolescence. Due to the observational nature of these studies, a descriptive approach was used to comment on any potential biases and/or limitations of the studies. This information was then summarised and analysed to ascertain the potential causal relationship between attachment at early to mid-childhood period to one's parent, especially the mother, and subsequent anxiety in early to late adolescence. The systematic literature searches and review process was summarised schematically in Figure 1 following the PRISMA chart format [15].

[INSERT FIGURE 1 HERE] 


\section{RESULTS}

An extensive search was conducted, while applying the procedures described in the methods, resulting in 11 articles on a longitudinal or prospective study in the English language on the relationship between childhood attachment to parents and subsequent mental health problems [16-25]. Of these, 5 were selected as potential candidates for inclusion in the review for anxiety. A closer examination of the full text of these articles revealed that only 4 satisfied the selection criteria with sufficient information on the relationship between attachment problems in infancy/childhood and anxiety in a later stage of development [18$20,24]$. One of these included both anxiety and depression as the outcome measures [24]. Hence, it was also included on the list of articles to be analysed for results on anxiety. The main reasons for the exclusion of other articles were that they either did not provide sufficient information on the assessment of the exposure and/or the outcome variables, or the focus of the study was not on infancy/childhood attachment but attachment at a later stage of life development such as adolescence [22]. Detailed information was extracted from these articles and summarised in Table 1.

In terms of the study design, all but one utilised an observation approach to collect baseline data on mother-child attachment. Brumariu's study, due to the fact that the target participants were $3^{\text {rd }}$ grade children, was the only study which utilised a psychometric tool, the Attachment Security scale, to elicit responses from children [20]. The cohorts were followed for outcome measures on anxiety with follow-up periods ranging from 2 to 7 years. All but one of these studies were small scale, with a sample size less than one hundred. The largest study was a secondary data analysis study by Dalairre et al with more than 800 children and their parents and teachers [19]. For the outcome, namely anxiety, three of the studies used the psychometric approach with different measuring instruments for childhood anxiety $[19,20,24]$. Of these, two utilised a self-reported scale that sought responses from children on various scale items $[20,24]$. By design, one of these three used parents and teachers as informants to complete the Child Behavioural Check List (CBCL) questionnaires [19]. In another Dalairre's study, the Child Puppet Interview was used as a tool to collect data from child respondents [18]. It was also noted that the outcome measures, though generically under the classification of anxiety, varied across studies and included a range of anxietyrelated problems, such as separation anxiety, general anxiety, social anxiety, and generalised anxiety disorder symptoms. In all these studies, appropriate statistical analytical approaches were employed such as regression modelling and Structural Equation modelling with adjustments for some potential confounding factors. Two of these studies also explored the possible interactive or mediational effect of poor attachment with other variables on subsequent anxiety $[19,24]$. The results of these studies indicated infant/childhood attachment was significantly related to anxiety in the subsequent development of children. In the earlier study by Dalairre, it was found that children's self-reported separation anxiety at age 6 years differed significantly between the securely and insecurely attachment groups $\left(\mathrm{t}_{98}=2.48, \mathrm{p}=.015\right)$ with insecurely attached children rating significantly higher [18]. In another study by the same author, it was also found that insecure attachment of the child at 15 months and the number of negative life events interacted to predict both mothers' $(\beta=$ $\left.-.30, p<.01, f^{2}=.01\right)$ and teachers' $\left(\beta=-.33, p<.05, f^{2}=.02\right)$ reports of children's anxiety at first grade [19]. These results were echoed in the study by Brumariu and colleagues where, after adjusting for possible confounding variables, ambivalent attachment at baseline $\left(3^{\text {rd }}\right.$ grade) was a significant predictor of different types of social anxiety at reassessment 2 years later [20]. The most recent study by Lecompte also provides evidence suggesting disorganised attachment in preschoolers was significantly predictive of anxiety symptoms $\left.\left(\mathrm{F}_{(1,64)}=7.21, \mathrm{p}<0.01\right), \beta=0.30, p<.01\right)$ at follow-up 7 years later [24]. In terms of the 
limitations identified from these studies, the most common one was that, due to the sample size constrain, sub-group analyses or analyses by different types of attachment, could not be performed. By the same token, some interaction effects between attachment and other study variables on anxiety could not be carried out.

\section{DISCUSSIONS AND CONCLUSION}

Through reviewing the existing evidence provided by well-designed studies, the research team aims to examine the possible causal relationship between poor attachment at infancy and early childhood to the parent, mainly the mother, and the subsequent development of mental health problems in adolescence. As the first of a series, anxiety is the focus of the current study. It is hypothesized that poor attachment, including insecure and disorganised attachment, during infancy and early childhood has a detrimental effect on the development of the child and is a potential cause of mental health problems during adolescence. The results obtained from this review indicate that poor attachment at infancy and early childhood is significantly related to symptoms of anxiety or diagnosed anxiety disorders in adolescence. These results are consistent and in line with the finding in the literature and, in particular, the meta-analytical study by Gorh and colleagues [14], although the focus of their study was on generic internalizing symptoms [25-29]. Based on the longitudinal and prospective design of the included studies for review, the evidence provided is of a higher level in terms of an evidence-based model for medical and health research [30]. Hence, they lend greater confidence to the conclusion that the association between poor attachment at infancy and early childhood, and mental health problems in adolescence could be a causal relationship.

The results obtained from these empirical studies have raised an important question as to why poorly attached young children would have a higher risk of developing mental health problems at a later stage of development. In the original exposition of the Attachment Theory, Bowlby provided some insights in the mechanism of the potential causal relationship between attachment insecurity and psychopathology [1]. The possible mechanism or causal pathway between attachment insecurity and mental health problems has been succinctly summarised by Mikulincer and Shaver [31] who state that the fundamental reason for the development of mental health problems in individuals with poor attachment during early childhood lies in an increase in general vulnerability to mental disorders [31]. It is suggested that an enhancement in vulnerability is the result of attachment insecurity on three psychological apsects of the individual: self-representation, emotion regulation, and problems in interpersonal relationship [31]. For self-representation, poor attachment to a sensitive and responsive figure at infancy and early childhood fails to provide a foundation for a proper and healthy formation of selfhood resulting in a lack of self-cohesion. As the child develops, this may lead to self-doubt, lack of self-esteem, and the need to constantly seek approval from others $[32,33]$. In terms of emotion regulation, a secure attachment between the infant or young child and the parental figure through stable interactions allow the child to build up constructive emotion-regulation strategies and also learn how to use these strategies properly. Acknowledgement and proper expression of one's emotions has been identified as a very important aspect of good mental health. On the other hand, insecure attachment of an infant may result in a reliance on other attachment strategies for its own survival. These alternative strategies could be destructive in terms of preventing the child from developing essential social skills when interacting with others. This may result in a severe lack of communication skills and perception in interpersonal relationships, which in turn greatly affect the mental state of the individual [34]. 
There are some important implications of the results obtained from this study, particularly in terms of early prevention and intervention of mental health problems in adolescence. The potential causal relationship between attachment insecurity at infancy and early childhood, and the development of mental health problems at a later life stage, suggests possibilities for the creation of effective early prevention and intervention strategies for youth mental health issues. The importance of parent-and-child secure attachment should be strongly advocated in the pre-and-peri-and-postnatal period, as well as child health and early childhood settings. A better understanding of various attachment styles in parents-to-be and new parents would also be helpful to equip and prepare parents for better attachment with their children $[35,36]$. In fact, attachment has already become part of the parenting training program in some part of the world (website http://www.attachmentparenting.org/apifaqs/parenteducation). These training strategies should be more commonly provided to young parents or parents-to-be to provide better foundations for the mental health of their children.

In conclusion, results from the systematic review suggest that attachment insecurity in infancy and early childhood could be one of the causal factors, and is part of the causal pathway, of youth anxiety. More attention should be paid to enhancing the understanding of parents' knowledge in the attachment styles and skills of attachment of young children. This is potentially an early prevention and intervention strategy of youth mental health problems.

\section{DECLARATION}

Ethics approval and consent to participate

The study obtained ethics approval from the Human Research Ethics Committee of the University of Technology Sydney (UTS Ethics Application Number: ETH160765). This was a systematic review of the literature and did not involve any study participants, thus informed consent was not applicable.

Consent for publication

All co-authors have granted consent to publish this paper in Systematic Reviews

Availability of data and material

All materials and data were available online.

Competing interests

The authors declared no conflict of interest in any kind for the conduct of the study.

Funding

This study received no external funding support from any sources.

Authors' contributions

LTL, the principal investigator had designed the study, involved in the review of articles, data extraction, and writing the manuscript. AR involved in the systematic literature search of articles, selection of suitable articles, extraction of data, and writing the manuscript.

MKL also involved in the selection of articles, data extraction, and writing the manuscript.

Acknowledgements

No specific acknowledgement 


\section{REFERENCES}

1. Bowlby J (1997) The making and breaking of affectional bonds: I. Aetiology and psychopathology in the light of Attachment Theory. British J Psychiatry 130:201-210.

2. Ainsworth MDS, Blehar MC, Waters E, Wall S (1978) Patterns of attachment: A psychological study of the strange situation. Hillsdale, NJ: Erlbaum.

3. Main M, Hesse W (1990) Parents' unresolved traumatic experiences are related to infant disorganization attachment status: Is frightened and/or frightening parental behavior the linking mechanism. In: Greenberg M, Cicchetti D, Cummings E (eds) Attachment in the preschool years: Theory, research, and intervention. Chicago: University of Chicago Press.

4. Freud S (1905) Three essays on the theory of sexuality. In: Strachey J (ed) The complete psychology works of Sigmund Freud (Vol. 7). London: Hogarth.

5. Dubois-Comtois K, Moss E (2008) Beyond the dyad: do family interactions influence children's attachment representations in middle childhood? Attach Hum Dev 10:415431.

6. Alhusen JL, Hayat MJ, Gross D (2013) A longitudinal study of maternal attachment and infant developmental outcomes. Arch Womens Ment Health 16(6):521-529.

7. Kennedy M, Betts LR, Underwood JD (2014) Moving beyond the mother-child dyad: exploring the link between maternal sensitivity and siblings' attachment styles. J Genet Psychol 175:287-300.

8. Obsuth I, Hennighausen K, Brumariu IE, Lyons-Ruth K (2014) Disorganised behavior in adolescent -parent interaction: Relations to attachment state of mind, partner abuse, and psychopathology. Child Development 85:370-387.

9. Pickreign S E, To the SL, Rogosch FA, Cicchetti D (2013) Preventive interventions and sustained attachment security in maltreated children: A 12-month follow-up of a randomised controlled trial. Development and Psychopathology 25: 919-930.

10. Raby KL, Roisman GI, Fraley RC, Simpson JA (2015) The enduring predictive significance of early maternal sensitivity: Social and academic competence through age 32 years. Child Development 86:695-708.

11. Toth SI, Sturge-Apple ML, Rogosch FA, Cichetti D (2015) Mechanism of change: Testing how preventive intervention impact psychological and physiological stress functioning in mothers in neglectful families. Development and Psychopathology 27:1661-1674.

12. Zeanah CH, Gleason MM (2015) Annual research review: Attachement disorder in early childhood- Clinical presentation, cause, correlated, and treatment. Journal of Child Psychology and Psychiatry 56:207-222.

13. Fearson RP, Baskermanns-Kranenburg MJ, van Ijzendoorn MH, Lapsley A, Roisman GL (2010) The significance of insecure attachement and disorganization in the development of children's externalizing behavior: A meta-analytic study. Child Development 81:435-456.

14. Groh AM, Roisman GI, van Ijzendoorn MH, Baskermanns-Kranenburg MJ (2012) The significance of insecure and disorganization attachment for children's internalizing symptoms: A meta-analytic study. Child Development 83:591-610. 
15. Moher D, Liberati A, Tetzlaff J, Altman DG, The PRISMA Group (2009) Preferred Reporting Items for Systematic Reviews and Meta-Analyses: The PRISMA Statement. Ann Intern Med, 151(4).

16. Raja SN, McGee R, Stanton W (1992) Perceived attachments to parents and peers and psychological well-being in adolescence. Journal of Youth and Adolescence 21: 471485.

17. Sund AM, Wichstrøm L (2002) Insecure Attachment as a Risk Factor for Future Depressive Symptoms in Early Adolescence. J. Am. Acad. Child adolesc. Psychiatry 41:12:1478-1485.

18. Dalairre DH, Weinraub M (2005) Predicting children's separation anxiety at age 6: The contributions of infant-mother attachment security, maternal sensitivity, and maternal separation anxiety. Attachment \& Human Development 7:393-408.

19. Dalairre DH, Weinraub M (2007) Infant-mother attachment security and children's anxiety and aggression at first grade. Journal of Applied Developmental Psychology 28:477-492.

20. Brumariu LE, Kerns KS (2010) Mother-child attachment patterns and different types of anxiety symptoms: Is there specificity of relations? Child Psychiatry Hum Dev 41:663-674.

21. Priddis L, Howieson ND (2012) Insecure attachment patterns at five years. What do they tell us? Early Child Development and Care 182:45-58.

22. Jakobsen IS, Horwood J, Fergusson DM (2012) Childhood anxiety/withdrawal, adolescent parent-child attachment and later risk of depression and anxiety disorder. $\mathrm{J}$ Child Fam Stud 21:303-310.

23. Brenning K, Soenens B, Braet C, Beyers W (2013) Longitudinal dynamics of depressogenic personality and attachment dimensions in adolescence: An examination of associations with changes in depressive symptoms. Journal of Youth and Adolescence 42:1128-1144.

24. Lecompte V, Moss E, Cyr C, Pascuzzo K (2014) Preschool attachment, self-esteem and the development of preadolescent anxiety and depressive symptoms. Attachment \& Human Development 16:242-260.

25. Glazebrook K, Townsend E, Sayal K (2015) The role of attachment style in Predicting repetition of adolescent self-harm: A longitudinal study. Suicide and Life-Threatening Behavior 45: 664-678.

25. de Minzi MCR (2006) Loneliness and depression in middle and late childhood: The relationship to attachment and parental styles, The Journal of Genetic Psychology 167:189-210.

26. Cassidy J, Lichtenstein-Phelps J, Sibrava NJ, Thomas Jr CIL, Borkovec TD (2009) Generalized anxiety disorder: Connections with self-reported attachment. Behavior Therapy 40:23-38.

27. Sonja Breinholst S, Esbjørn BH, Reinholdt-Dunne ML (2015) Effects of attachment and rearing behavior on anxiety in normal developing youth: A mediational study. Personality and Individual Differences 81:155-161.

28. Bosmans G, De Smedt B (2015) Insecure attachment is associated with math anxiety in middle childhood. Front. Psychol 6:1596. 
29. Borelli JL, David DH, Crowley MJ, Mayes LC (2010) Links between disorganized attachment classification and clinical symptoms in school-aged children. J Child Fam Stud 19:243-256.

31. Mikulincer M, Shaver PR (2012). An attachment perspective on psychopathology. World Psychiatry 11:11-15.

32. Park LE, Crocker J, Mickelson KD (2004) Attachment styles and contingencies of self-worth. Pers Soc Psychol Bull 30:1243-1254.

30. Mayer D (2010) Essential Evidence-Base Medicine, 2nd Ed. Cambridge,UK: Cambridge University Press.

33. Wei M, Heppneer PP, Russell DW, et al (2006) Maladaptive perfectionism and ineffective coping as mediators between attachment and future depression: a prospective analysis. J Couns Psychol 53:67-79.

34. Larose S, Bernier A (2001) Social support process: mediators of attachment state of mind and adjustment in late adolescence. Attach Him Dev 3:96-120.

35. Hazan C, Shaver PR (1987) Romantic love conceptualized as an attachment process. Journal Person Soc Psycho 52:511-524.

36. Dozier M, Lindhiem O, Lewis E, Bick J, Bernard K, Peloso E (2009) Effects of a foster parent training program on young children's attachment behaviors: Preliminary evidence from a randomized clinical trial. Child Adolesc Social Work J 26: 321-332. 
Table 1. Information extracted from individual longitudinal or prospective cohort studies on infant/childhood attachment and anxiety in children and adolescents.

\begin{tabular}{|c|l|l|l|l|l|l|l|}
\hline $\begin{array}{c}\text { Refere } \\
\text { nce } \\
\text { (Autho } \\
\text { r, year, } \\
\text { place) }\end{array}$ & Participants & $\begin{array}{l}\text { Study } \\
\text { methodolo }\end{array}$ & $\begin{array}{l}\text { Exposure, } \\
\text { confounding } \\
\text { variables \& } \\
\text { measures }\end{array}$ & $\begin{array}{l}\text { Outcome } \\
\text { variable } \\
\text { measures }\end{array}$ & $\begin{array}{l}\text { Method of } \\
\text { analysis and } \\
\text { variables adjusted }\end{array}$ & Results & Comments \\
& & & & & \\
\hline
\end{tabular}




\begin{tabular}{|c|c|c|c|c|c|c|c|}
\hline $\begin{array}{l}\text { Dalairre, } \\
(2005) \text {, } \\
\text { Pennsylv } \\
\text { ania } \\
\text { USA }\end{array}$ & $\begin{array}{l}\text { This was a } \\
\text { secondary data } \\
\text { analysis utilising the } \\
\text { data collected for } \\
\text { Phase I and II of the } \\
\text { National Institute } \\
\text { Child Health and } \\
\text { Human } \\
\text { Development Study } \\
\text { of Early Child Care } \\
\text { and Youth } \\
\text { Development } \\
\text { (NICHD SECCYD). } \\
\text { An original sample } \\
\text { of } 136 \text { families were } \\
\text { drawn from the } \\
\text { original study. } \\
\text { Ninety-nine mother } \\
\text { and child dyads (N } \\
\text { = 99) were recruited } \\
\text { in this study. The } \\
\text { mean age of } \\
\text { children at the time } \\
\text { of final assessment } \\
\text { was } 6 \text { years and } 3 \\
\text { months with } 52 \% \\
\text { males. }\end{array}$ & $\begin{array}{l}\text { Mother and } \\
\text { child dyads } \\
\text { were } \\
\text { followed } \\
\text { since the } \\
\text { child was } 1 \\
\text { month old } \\
\text { until the } \\
\text { child were at } \\
\text { the first } \\
\text { grade, about } \\
6 \text { years old. } \\
\text { Baseline } \\
\text { assessments } \\
\text { on important } \\
\text { variables } \\
\text { were } \\
\text { conducted at } \\
\text { the time } \\
\text { when the } \\
\text { child was } 6 \\
\text { months old } \\
\text { and then at } \\
\text { regular } \\
\text { intervals. }\end{array}$ & $\begin{array}{l}\text { Exposure: Child } \\
\text { Attachment to } \\
\text { mother, } \\
\text { particularly } \\
\text { maternal secure } \\
\text { attachment vs } \\
\text { insecure } \\
\text { attachment. } \\
\text { Measures: } \\
\text { The Strange } \\
\text { Situation } \\
\text { procedure used to } \\
\text { assess infant } \\
\text { attachment } \\
\text { security by } \\
\text { observation with } \\
\text { videos taping. } \\
\text { Assessment was } \\
\text { conducted when } \\
\text { the child was } 15 \\
\text { months. } \\
\text { Confounding } \\
\text { variables: } \\
\text { Maternal } \\
\text { sensitivity } \\
\text { evaluated by the } \\
\text { free play } \\
\text { interaction tasks } \\
\text { with the child. } \\
\text { Maternal } \\
\text { separation anxiety } \\
\text { measured by the }\end{array}$ & $\begin{array}{l}\text { Outcome: } \\
\text { Child } \\
\text { separation } \\
\text { anxiety } \\
\text { Measures: } \\
\text { Modified } \\
\text { Child } \\
\text { Puppet } \\
\text { Interview } \\
\text { designed to } \\
\text { elicit } \\
\text { children's } \\
\text { perception } \\
\text { of their } \\
\text { feelings } \\
\text { and } \\
\text { behaviours. } \\
\text { Assessment } \\
\text { s were } \\
\text { conducted } \\
\text { when the } \\
\text { child was } 6 \\
\text { years old. }\end{array}$ & $\begin{array}{l}\text { Relations between } \\
\text { children's separation } \\
\text { anxiety and infant- } \\
\text { mother attachment } \\
\text { security was } \\
\text { examined with t-tests, } \\
\text { analysis of } \\
\text { variance (ANOVAs), } \\
\text { and pairwise } \\
\text { comparisons. } \\
\text { Simultaneous } \\
\text { regression } \\
\text { analysis tested the } \\
\text { incremental } \\
\text { predictive utility of } \\
\text { each of the predictor } \\
\text { variables. }\end{array}$ & $\begin{array}{l}\text { Bivariate } \\
\text { analysis results } \\
\text { suggested that } \\
\text { Children's self- } \\
\text { reported } \\
\text { separation } \\
\text { anxiety at age } 6 \\
\text { years differed } \\
\text { significantly } \\
\text { between the } \\
\text { securely and } \\
\text { insecurely } \\
\text { attachment } \\
\text { groups [t98=2.48, } \\
\text { p=.015] with } \\
\text { insecurely } \\
\text { attached } \\
\text { children rated } \\
\text { significantly } \\
\text { higher. } \\
\text { Regression } \\
\text { analysis results } \\
\text { also confirmed } \\
\text { that infant- } \\
\text { mother } \\
\text { attachment was } \\
\text { a significant } \\
\text { predictor of } \\
\text { child's } \\
\text { separation } \\
\text { anxiety at } 6 \\
\text { years old. }\end{array}$ & $\begin{array}{l}\text { Limitations: } \\
\text { The study was limited } \\
\text { by a small sample and } \\
\text { the attrition of the } \\
\text { original recruited } \\
\text { sample. A small } \\
\text { sample precluded the } \\
\text { study from testing the } \\
\text { relationship between } \\
\text { subtypes of the } \\
\text { insecurely attachment } \\
\text { and separation anxiety } \\
\text { in children. }\end{array}$ \\
\hline
\end{tabular}




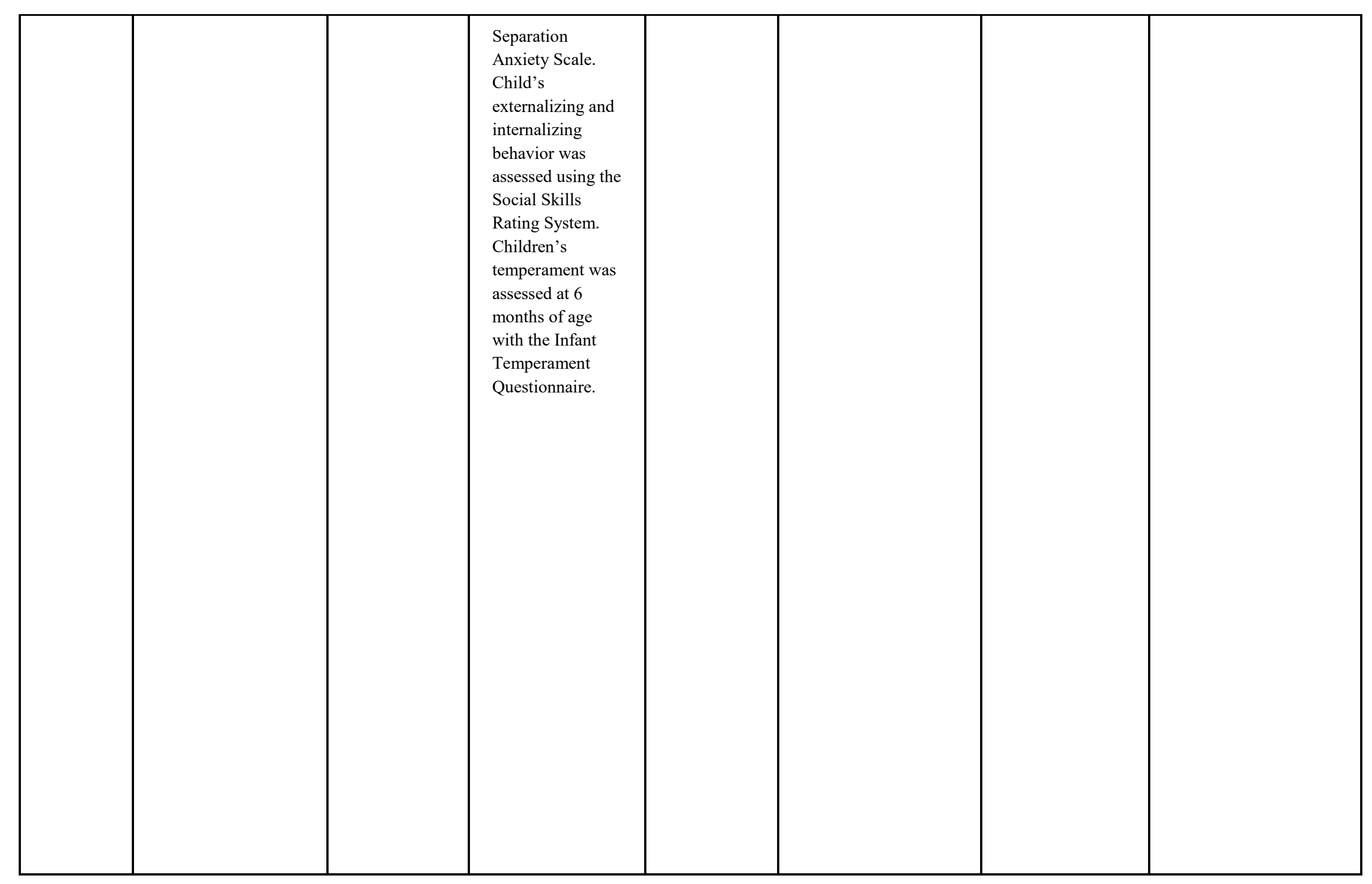




\begin{tabular}{|c|c|c|c|c|c|c|c|}
\hline $\begin{array}{l}\text { Dalairre } \\
(2007) \text {, } \\
\text { Pennsylv } \\
\text { ania } \\
\text { USA }\end{array}$ & $\begin{array}{l}\text { Similar to the report } \\
\text { above, this was also } \\
\text { a secondary data } \\
\text { analysis using data } \\
\text { collected for Phase I } \\
\text { and II of the } \\
\text { National Institute } \\
\text { Child Health and } \\
\text { Human } \\
\text { Development Study } \\
\text { of Early Child Care } \\
\text { and Youth } \\
\text { Development } \\
\text { (NICHD SECCYD). } \\
\text { 1,364 families were } \\
\text { recruited to the } \\
\text { original study } \\
\text { starting in } 1991 . \\
\text { Though not all of } \\
\text { the } 1364 \text { original } \\
\text { participants } \\
\text { completed each and } \\
\text { every assessment, } \\
\text { there are complete } \\
\text { data from } 866 \\
\text { mother-child, } 662 \\
\text { father-child, and } \\
831 \text { teacher-child } \\
\text { dyads for the } \\
\text { regression analyses }\end{array}$ & $\begin{array}{l}\text { Families } \\
\text { were } \\
\text { followed } \\
\text { since the } \\
\text { child was } 1 \\
\text { month until } \\
\text { the time of } \\
\text { study } \\
\text { outcome } \\
\text { assessment } \\
\text { when the } \\
\text { child at first } \\
\text { grade. }\end{array}$ & $\begin{array}{l}\text { Exposure: } \\
\text { Child Attachment } \\
\text { to mother, } \\
\text { particularly } \\
\text { maternal secure } \\
\text { attachment vs } \\
\text { insecure } \\
\text { attachment. } \\
\text { Measures: } \\
\text { The Strange } \\
\text { Situation } \\
\text { procedure used to } \\
\text { assess infant } \\
\text { attachment } \\
\text { security by } \\
\text { observation with } \\
\text { videos taping. } \\
\text { Assessment was } \\
\text { conducted when } \\
\text { the child was } 15 \\
\text { months. } \\
\text { Confounding } \\
\text { variables: } \\
\text { Mothers reported } \\
\text { the number of } \\
\text { negative life } \\
\text { events (NLE) the } \\
\text { family } \\
\text { experienced over } \\
\text { the past } 12 \\
\text { months when the } \\
\text { child was } 4.5 y r s \\
\text { using the Life } \\
\text { a }\end{array}$ & $\begin{array}{l}\text { Outcome: } \\
\text { Child's } \\
\text { anxiety. } \\
\text { Measures: } \\
\text { Assessed } \\
\text { using Child } \\
\text { Behaviour } \\
\text { Checklist } \\
\text { (CBCL) } \\
\text { completed } \\
\text { by mothers, } \\
\text { fathers, and } \\
\text { teachers at } \\
1^{\text {st }} \text { Grade. }\end{array}$ & $\begin{array}{l}\text { in the prediction of } \\
\text { children's anxious } \\
\text { behaviours, a series } \\
\text { of hierarchical } \\
\text { regression analyses } \\
\text { were } \\
\text { performed with a } \\
\text { focus on the } \\
\text { interaction effect of } \\
\text { NLE and attachment } \\
\text { on anxiety. } \\
\text { Additional analyses } \\
\text { used latent variable } \\
\text { Structural Equation } \\
\text { Modelling (SEM) } \\
\text { with the maximum } \\
\text { likelihood methods } \\
\text { for parameter } \\
\text { estimates. }\end{array}$ & $\begin{array}{l}\text { Attachment } \\
\text { security at } 15 \\
\text { months and } \\
\text { number of NLE } \\
\text { interacted to } \\
\text { predict both } \\
\text { mothers' ( } \beta= \\
-.30, p<.01, f^{2} \\
=.01) \text { and } \\
\text { teachers' ( } \beta= \\
-.33, p<.05, f^{2} \\
=.02) \text { reports of } \\
\text { children's } \\
\text { anxiety. } \\
\text { These results } \\
\text { were confirmed } \\
\text { with the SEM } \\
\text { approach that an } \\
\text { interaction } \\
\text { between NLE } \\
\text { and Attachment } \\
\text { security at } 15 \\
\text { months was a } \\
\text { significant } \\
\text { predictor of } \\
\text { child's anxiety } \\
\text { at first grade. }\end{array}$ & $\begin{array}{l}\text { Strength of the study: } \\
\text { Large sample size that } \\
\text { allowed an } \\
\text { investigation on the } \\
\text { interaction effect of } \\
\text { other variables with } \\
\text { Attachment on } \\
\text { anxiety. } \\
\text { Inclusion of a number } \\
\text { of possible } \\
\text { confounding variables } \\
\text { of childhood anxiety. } \\
\text { Multiple informants } \\
\text { for richer data and } \\
\text { better validity of } \\
\text { results. }\end{array}$ \\
\hline
\end{tabular}




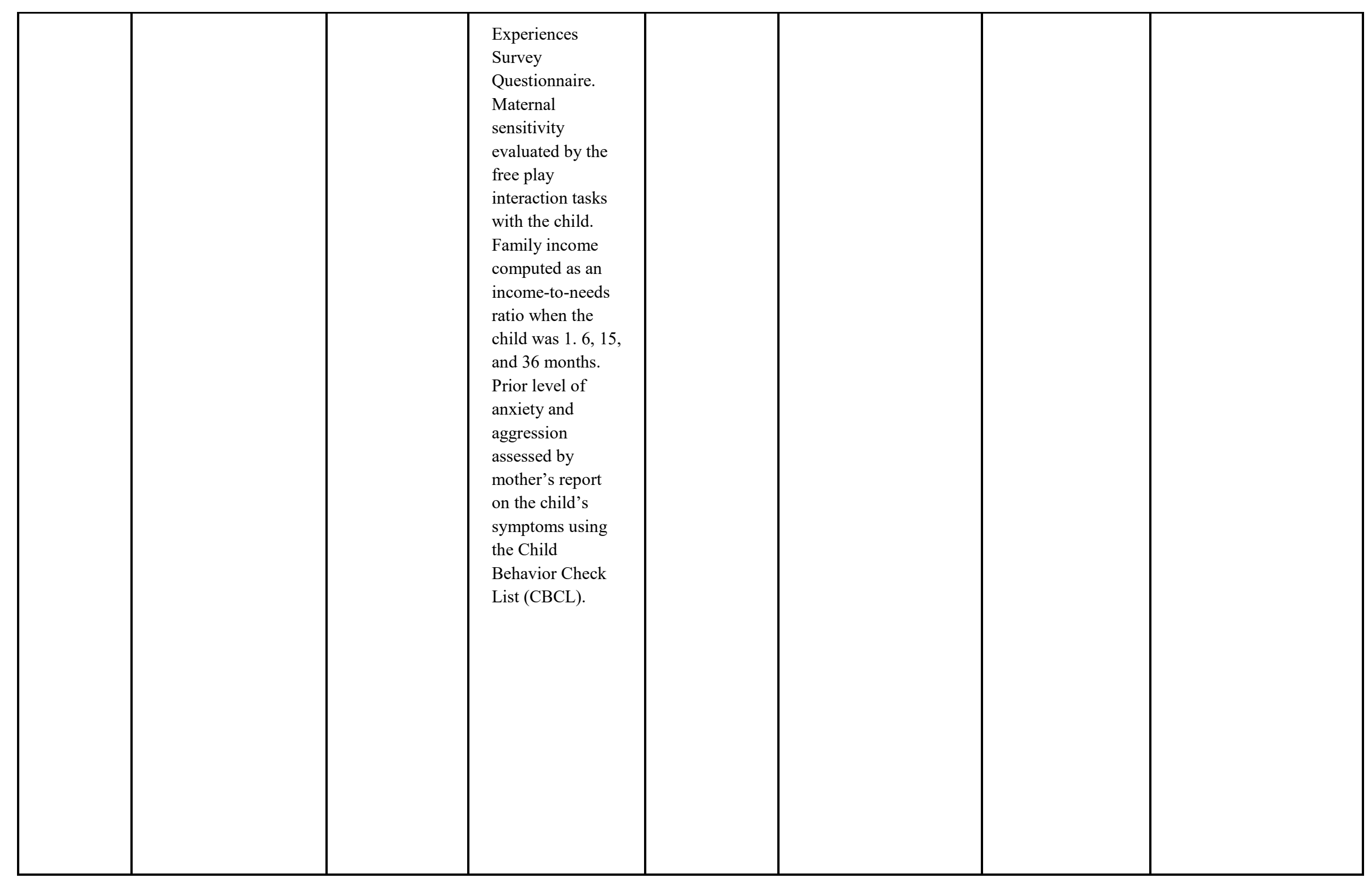




\begin{tabular}{|c|c|c|c|c|c|c|c|}
\hline $\begin{array}{l}\text { Brumari } \\
\text { u (2008), } \\
\text { Kent } \\
\text { USA }\end{array}$ & $\begin{array}{l}\text { Mother and child } \\
\text { dyads were recruited } \\
\text { when the child was } \\
\text { in the } 3^{\text {rd }} \text { grade with } \\
104 \text { dyads ( } 51 \text { girls, } \\
53 \text { boys, mean }= \\
9.1 \mathrm{yrs} \text {; } \mathrm{SD}= \\
0.45 \mathrm{yrs}) .74 \text { dyads } \\
\text { were reassessed } \\
\text { again when he child } \\
\text { reached } 5^{\text {th }} \text { grade } \\
\text { (mean }=10.92 \mathrm{yrs} \text {; } \\
\mathrm{SD}=0.42 \mathrm{yrs)}\end{array}$ & $\begin{array}{l}\text { Mother } \\
\text { dyads were } \\
\text { assessed in a } \\
\text { 2-hour } \\
\text { laboratory } \\
\text { session for } \\
\text { baseline } \\
\text { measure and } \\
\text { then } \\
\text { reassessed } 2 \\
\text { years later. } \\
\text { During } \\
\text { baseline } \\
\text { assessment } \\
\text { mother and } \\
\text { child } \\
\text { attachment } \\
\text { was } \\
\text { measured } \\
\text { using a self- } \\
\text { reported } \\
\text { questionnair } \\
\text { e. Social } \\
\text { anxiety of } \\
\text { the child was } \\
\text { evaluated } 2 \\
\text { years later. }\end{array}$ & $\begin{array}{l}\text { Exposure: } \\
\text { Mother-child } \\
\text { Attachment } \\
\text { security with } \\
\text { different types of } \\
\text { attachment } \\
\text { patterns. } \\
\text { Measures: } \\
\text { Attachment } \\
\text { Security scale } \\
\text { with 15 items and } \\
\text { a 4-point Likert } \\
\text { response rating } \\
\text { aiming to assess } \\
\text { children's } \\
\text { perceptions of } \\
\text { their attachment } \\
\text { with their } \\
\text { mothers. } \\
\text { Confounding } \\
\text { variables: } \\
\text { Child's coping } \\
\text { measured by the } \\
\text { Coping Strategies } \\
\text { Questionnaire. }\end{array}$ & $\begin{array}{l}\text { Outcome: } \\
\text { Child's } \\
\text { social } \\
\text { anxiety in } \\
\text { middle } \\
\text { childhood } \\
\text { including } \\
\text { fear of } \\
\text { negative } \\
\text { evaluation, } \\
\text { social } \\
\text { avoidance } \\
\text { and distress } \\
\text { in new } \\
\text { situation, } \\
\text { and general } \\
\text { social } \\
\text { avoidance } \\
\text { and } \\
\text { distress. } \\
\text { Measures: } \\
\text { A revised } \\
\text { version of } \\
\text { the self- } \\
\text { reported } \\
\text { Social } \\
\text { Anxiety } \\
\text { Scale for } \\
\text { Children. }\end{array}$ & $\begin{array}{l}\text { Correlations were } \\
\text { calculated between } \\
\text { social anxiety } \\
\text { variables and scores } \\
\text { for each attachment } \\
\text { pattern } \\
\text { Regression analyses } \\
\text { were used to assess } \\
\text { how the three } \\
\text { attachment patterns } \\
\text { (secure, ambivalent } \\
\text { and avoidant) } \\
\text { collectively and } \\
\text { uniquely predicted } \\
\text { each of the } \\
\text { three social anxiety } \\
\text { dimensions (Fear of } \\
\text { Negative Evaluation } \\
\text { from Peers, Social } \\
\text { Avoidance and } \\
\text { Distress Specific to } \\
\text { New Situation, and } \\
\text { Generalised Social } \\
\text { Avoidance and } \\
\text { Distress) }\end{array}$ & $\begin{array}{l}\text { After adjusting } \\
\text { for possible } \\
\text { confounding } \\
\text { variables, } \\
\text { including age } \\
\text { and sex, } \\
\text { ambivalent } \\
\text { attachment at } \\
\text { baseline was the } \\
\text { only significant } \\
\text { predictor of all } \\
\text { three types of } \\
\text { social anxiety at } \\
\text { reassessment. }\end{array}$ & $\begin{array}{l}\text { Limitations: } \\
\text { Small sample size } \\
\text { provided limited } \\
\text { power for the study. } \\
\text { Reliance on self- } \\
\text { reported } \\
\text { questionnaires to } \\
\text { assess both } \\
\text { Attachment and social } \\
\text { anxiety introduced } \\
\text { shared method } \\
\text { variance, which may } \\
\text { increase the estimates } \\
\text { of the associations } \\
\text { between the two types } \\
\text { of measures. } \\
\text { It would be beneficial } \\
\text { to include reports of } \\
\text { social anxiety } \\
\text { symptoms from other } \\
\text { reliable sources (e.g., } \\
\text { parents, teachers) }\end{array}$ \\
\hline
\end{tabular}




\begin{tabular}{|c|c|c|c|c|c|c|c|}
\hline $\begin{array}{l}\text { Lecompt } \\
\text { e (2014), } \\
\text { Montreal } \\
\text {, Canada }\end{array}$ & $\begin{array}{l}\text { As part of an } \\
\text { ongoing } \\
\text { longitudinal project } \\
\text { on developmental } \\
\text { adaptation, mother- } \\
\text { child dyads were } \\
\text { recruited when the } \\
\text { child was } 3-4 \text { years } \\
\text { old through } \\
\text { preschools in } \\
\text { various SES } \\
\text { communities in } \\
\text { Montreal. } \\
68 \text { ( } 72 \% \text { ) of the } \\
\text { original sample } \\
\text { were included in } \\
\text { this study with } 33 \\
\text { girls and } 35 \text { boys } \\
\text { (mean age }=3.7 y r s ; \\
\text { SD = 4.4mths). } \\
\text { They were followed } \\
\text { for } 7 \text { years (mean } \\
\text { age }=11.7 y r s ; S D= \\
4.3 \text { mths) for the } \\
\text { study outcome } \\
\text { measure. }\end{array}$ & $\begin{array}{l}\text { Mother-child } \\
\text { dyads were } \\
\text { assessed at } \\
\text { the } \\
\text { university } \\
\text { laboratory } \\
\text { for baseline } \\
\text { data } \\
\text { collection. } \\
\text { They were } \\
\text { reassessed at } \\
\text { the } \\
\text { laboratory } \\
\text { again } 7 \text { years } \\
\text { later. }\end{array}$ & $\begin{array}{l}\text { Exposure: } \\
\text { Mother-child } \\
\text { Attachment } \\
\text { security with } \\
\text { different types of } \\
\text { attachment } \\
\text { patterns. } \\
\text { Measures: } \\
\text { The Separation- } \\
\text { reunion procedure } \\
\text { was used to } \\
\text { assess mother- } \\
\text { child attachment } \\
\text { security by } \\
\text { observation. } \\
\text { Attachment } \\
\text { patterns were } \\
\text { classified in } \\
\text { secure, insecure- } \\
\text { organised, and } \\
\text { disorganised. } \\
\text { Confounding } \\
\text { variables: } \\
\text { Socio- } \\
\text { demographic } \\
\text { variables } \\
\text { including } \\
\text { mother's age, } \\
\text { income, and level } \\
\text { of education. } \\
\text { Self-competence } \\
\text { of the child }\end{array}$ & $\begin{array}{l}\text { Outcome: } \\
\text { Generalised } \\
\text { Anxiety } \\
\text { Disorder } \\
\text { symptoms } \\
\text { Measures: } \\
\text { Assessed } \\
\text { by the self- } \\
\text { reported } \\
\text { Dominic } \\
\text { Interactive } \\
\text { Questionnai } \\
\text { re }\end{array}$ & $\begin{array}{l}\text { Differences in } \\
\text { adolescent anxiety } \\
\text { among various } \\
\text { groups of preschool } \\
\text { attachment were } \\
\text { tested using } \\
\text { ANCOVA with } \\
\text { control of } \\
\text { confounding } \\
\text { variables. Pairwise } \\
\text { comparisons were } \\
\text { also conducted as } \\
\text { post-hoc analyses. } \\
\text { Hierarchical } \\
\text { regression analyses } \\
\text { were also used to } \\
\text { further examine the } \\
\text { possible mediational } \\
\text { role of self-esteem on } \\
\text { anxiety. }\end{array}$ & $\begin{array}{l}\text { Results } \\
\text { indicated } \\
\text { significant } \\
\text { differences in } \\
\text { anxiety scores } \\
\text { across three } \\
\text { different } \\
\text { attachment } \\
\text { groups } \\
\text { (F(2,64) }=4.37 \text {, } \\
\text { p }<0.05) \text {. Post } \\
\text { hoc analyses } \\
\text { results suggested } \\
\text { that preschool } \\
\text { disorganized } \\
\text { attachment } \\
\text { scored } \\
\text { significant } \\
\text { higher on } \\
\text { anxiety } \\
\text { symptoms in } \\
\text { comparison to } \\
\text { the securely } \\
\text { attached group } \\
(\mathrm{t} 64=-2.88, \mathrm{p} \\
<.05, \mathrm{~d}=.72) \text {. } \\
\text { Regression } \\
\text { results also } \\
\text { indicated that, } \\
\text { after adjusting } \\
\text { for demographic } \\
\text { variables and } \\
\text { self-esteem, } \\
\text { preschool }\end{array}$ & $\begin{array}{l}\text { Limitations: } \\
\text { Owing to the restricted } \\
\text { sample, both the } \\
\text { avoidant and } \\
\text { ambivalent groups } \\
\text { were combined into an } \\
\text { insecure-organized } \\
\text { group, thus limiting } \\
\text { the possibility of } \\
\text { examining more } \\
\text { specific differences } \\
\text { between these groups. } \\
\text { The use of a } \\
\text { nonclinical sample } \\
\text { also contributed to this } \\
\text { narrower range of } \\
\text { insecure } \\
\text { classifications, as well } \\
\text { as behavior problem } \\
\text { scores. }\end{array}$ \\
\hline
\end{tabular}




\begin{tabular}{|l|l|l|l|l|l|l|}
\hline & & $\begin{array}{l}\text { measured by the } \\
\text { Self- Perception } \\
\text { Profile of } \\
\text { Children (SPPC) }\end{array}$ & & & & $\begin{array}{l}\text { disorganised } \\
\text { attachment was } \\
\text { still significantly } \\
\text { predictive of } \\
\text { anxiety } \\
\text { symptoms } \\
\left(\mathrm{F}_{(1,64)=7.21,}\right. \\
\mathrm{p}<0.01), \beta= \\
0.30, p<.01) .\end{array}$ \\
\hline
\end{tabular}


Figure 1. PRISMA flowchart of search for peer-reviewed journal articles
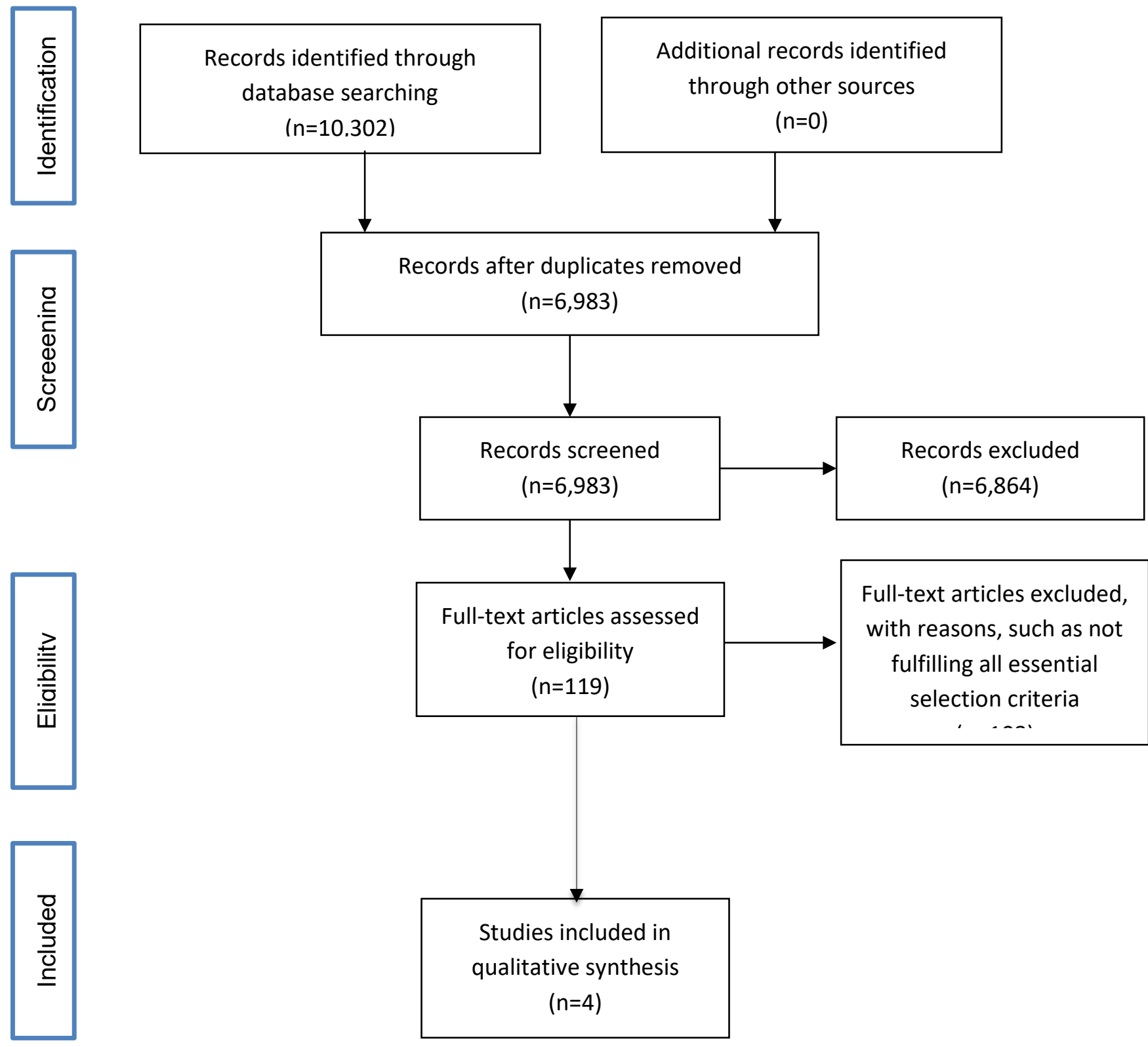

Studies included in qualitative synthesis $(n=4)$ 
